\title{
Metastatic prostate cancer: clinical aspects and treatment limitations in a university hospital center in Senegal
}

\author{
Cyrille Ze Ondo ${ }^{1}$, Abdoulaye Ndiath ${ }^{1 *}$ (i), Alioune Sarr ${ }^{1}$, Amath Thiam², Babacar Sine ${ }^{1}$, Ousmane Sow', \\ Ndiaga Seck Ndour', Babacar Diao', Papa Ahmed Fall ${ }^{3}$ and Alain Khassim Ndoye ${ }^{1}$
}

\begin{abstract}
Background: Prostate cancer is most often diagnosed at the metastatic stage in many sub-Saharan African countries. The objective of our study is to analyze the management of metastatic prostatic adenocarcinoma based on epidemiological, clinical, therapeutic and evolutionary aspects in developing country context.

Methods: Retrospective study collecting 276 patients from January 1st, 2012 to December 31st, 2019 in Aristide Le Dantec University Hospital in Dakar, Senegal. Parameters studied: age, family history of prostate cancer, reasons for consultation, total Prostate Specific Antigen (PSA), anatomic pathology examination, extension assessment, treatment, nadir PSA, castration resistance, and overall survival.

Results: The average age was 71.4 years. A family history of prostate cancer was noted in 21 patients. Spinal pain was the most noted reason for consultation. The average total PSA level was $1967.1 \mathrm{ng} / \mathrm{ml}$. The majority of patients had moderately differentiated prostate cancer. Bone metastases were the most common. All patients had androgen suppression. A tumor cytoreduction was performed in 89 patients. The average nadir PSA was $193 \mathrm{ng} / \mathrm{ml}$ as early as the sixth month. The time to onset of castration resistance ranged from 6 to 30 months. Abiraterone acetate was used in seven patients and docetaxel in 43 patients. The overall survival of the patients was $19.8 \pm 1.2$ months.
\end{abstract}

Conclusion: Metastatic prostate cancer was most often symptomatic at the time of diagnosis. Second-line treatments were rarely used during castration resistance. Overall survival was low.

Keywords: Prostate cancer, Metastasis, Castration resistance, Management, Senegal

\section{Background}

Prostate cancer is most often diagnosed at the metastatic stage in many sub-Saharan African countries, because the majority of patients are late in coming for treatment $[1,2]$. The prognosis for metastatic prostate cancer has improved significantly in recent years through better therapeutic management of patients with resistance to castration $[3,4]$. The use of new therapies in this context,

\footnotetext{
${ }^{*}$ Correspondence: ndiath.ndiath23@gmail.com

${ }^{1}$ Urology Department, University Hospital Center Aristide Le Dantec,

Dakar, Senegal

Full list of author information is available at the end of the article
}

such as second-line hormone therapies targeting the androgen receptor or taxane-based chemotherapy, has contributed to an improvement in patients' overall survival and quality of life [5]. The objectives of this study were to analyse the current management of metastatic prostate cancer with emphasis on its epidemiological, clinical, therapeutic and evolutionary aspects in a university hospital centre in our country.

\section{Methods}

This is a retrospective, descriptive and analytical study on 276 patients who were followed for metastatic adenocarcinoma of the prostate from January 1, 2012 to 


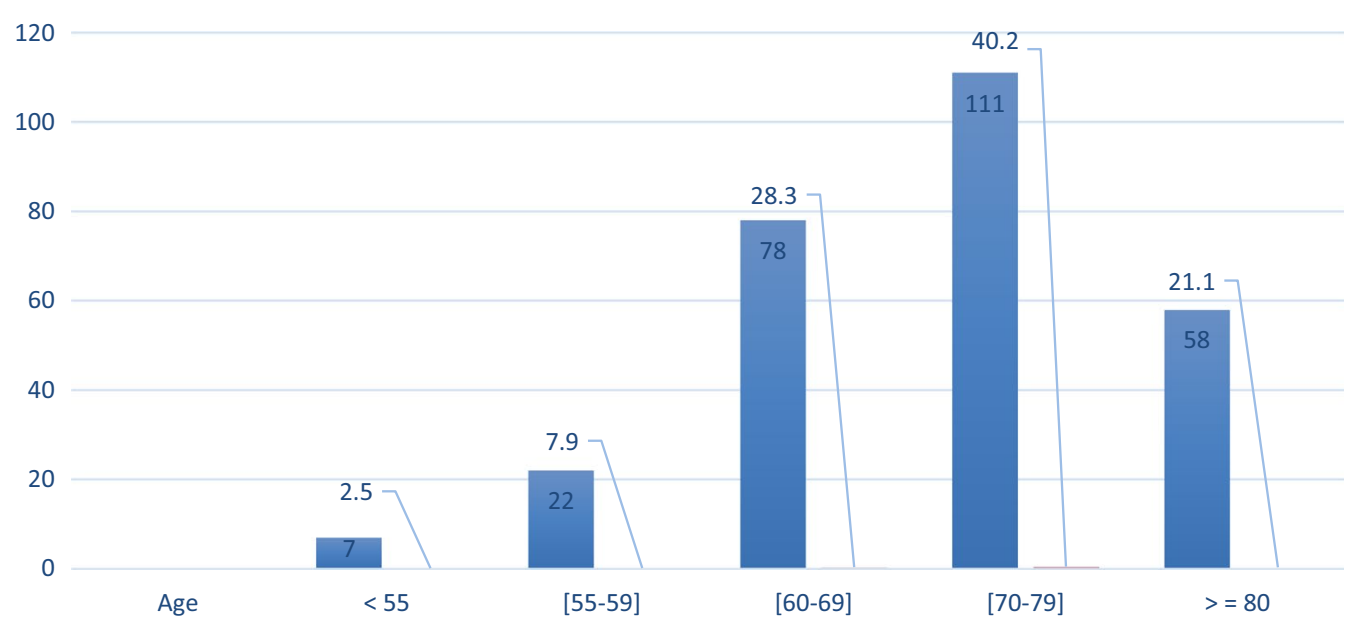

Fig. 1 Age distribution of patients

December 31, 2019 in Aristide Le Dantec University Hospital in Dakar, Senegal. The following variables were studied: age, family history of prostate cancer (existence of at least three cases of prostate cancer in first-or second-degree relatives or presence of at least two cases of prostate cancer diagnosed before the age of 55 in firstor second-degree relatives [6]), reasons for consultation, total PSA (PSA is measured by ELISA), pathology data (International Society of Urological Pathology ISUP 2016 classification [7]), extension status, treatment, PSA nadir, castration resistance (radiobiological progression of prostate cancer with a testosteronemia rate $\leq 0.5 \mathrm{ng} /$ $\mathrm{ml}[8]$ ) and overall survival. The approval of the hospital's ethics committee is obtained for this study. The data were entered into Excel 2010 and analysed using the SPSS 20.0 software.

\section{Results}

The average age of the patients was 71.4 years (46 and 98). The most represented age group was $70-79$ years (40.2\%). We also had a representation of seven patients under 55 years of age, a rate of $2.5 \%$ of cases (Fig. 1). A family history of prostate cancer was noted in 21 patients (7.6\%) including 15 first-degree relatives and $6 \mathrm{~s}$-degree relatives. Spinal pain (46.9\%) and changes in general condition (36.6\%) were the most common reasons for consultation (Table 1). The average total PSA level was $1967.1 \mathrm{ng} / \mathrm{ml}(9.6 \mathrm{ng} / \mathrm{ml}$ and $32047 \mathrm{ng} / \mathrm{ml})$. The exact value of the PSA level was not specified for 15 patients (5.4\%), however, they all had a PSA level $>100 \mathrm{ng} / \mathrm{ml}$. The majority of patients (42\%) had moderately differentiated prostate cancer (Table 2). CT scan (69.9\%) was the most frequently performed imaging test for the extension workup. Bone metastases $(82.6 \%)$ were the
Table 1 Distribution of patients by reason for consultation

\begin{tabular}{lcc}
\hline Reason for consultation & Number & $\%$ \\
\hline Alteration in general condition & 101 & 36.6 \\
lower urinary tract symptoms & 84 & 30.5 \\
Spinal pain & 129 & 46.9 \\
paraplegia & 71 & 25.8 \\
Bladder urine retention & 75 & 27.1 \\
Hematuria & 11 & $4 \%$ \\
Prostate cancer screening & 5 & 1.8 \\
\hline
\end{tabular}

Table 2 Patient distribution by Gleason score

\begin{tabular}{lcc}
\hline Gleason score & Number & Percentage (\%) \\
\hline $6(3+3)$ & 93 & 33.7 \\
$7(3+4)$ & 23 & 8.3 \\
$7(4+3)$ & 116 & 42.0 \\
$8(3+5)$ & 1 & 0.4 \\
$8(4+4)$ & 28 & 10.1 \\
$9(4+5)$ & 6 & 2.2 \\
$9(5+4)$ & 9 & 3.3 \\
Total & 276 & 100.0 \\
\hline
\end{tabular}

most common and 87 patients (38.2\%) had more than one bone location (Table 3) In addition, all patients had androgen suppression. Pulpectomy (86.4\%) was the most common type of castration. Tumor cyto-reduction was performed on 89 patients (32.2\%) and consisted in the majority (88.7\%) of cases of open cervico-prostatic recess (Table 4). Treatment was not carried out in 11 patients (4\%), due to refusal of surgical castration and or lack of 
Table 3 The characteristics of the extension balance sheet

\begin{tabular}{lcl}
\hline & Number & Percentage (\%) \\
\hline Imaging & 55 & \\
Radiography of the spine & 22 & 89.3 \\
Chest X-ray & 193 & 69.9 \\
Scanner & 21 & 7.9 \\
MRI & 24 & 8.7 \\
Bone scan Te 99 & & \\
Metastasis sites & 6 & 2.2 \\
Brain & 56 & 20.3 \\
Lymph node & 52 & 18.8 \\
Liver & 78 & 28.3 \\
Lungs & 228 & 82.6 \\
Dorsolumbar rachis & 2 & 0.7 \\
Eyes and testicles & & \\
\hline
\end{tabular}

Table 4 Distribution of patients according to treatments received

\begin{tabular}{lcl}
\hline Type of treatment & Number & Percentage (\%) \\
\hline Cyto-réduction tumorale & 89 & 100 \\
Cervico-prostatic recess & 65 & 73 \\
RTUP & 24 & 27 \\
Androgenic suppression & 265 & 100 \\
Medical & 36 & 13.6 \\
Surgical & 229 & 86.4 \\
Biphosphonates & 10 & 3.6 \\
Laminectomy & 4 & 1.4 \\
Radiotherapy analgesic & 21 & 7.6 \\
\hline
\end{tabular}

financial means for medical castration. The mean nadir PSA was $193 \mathrm{ng} / \mathrm{ml}(0.3 \mathrm{ng} / \mathrm{ml}$ and $4385 \mathrm{ng} / \mathrm{ml})$ and was reached after 6 months. The time of onset of resistance to castration was varied, most often occurring between 6 and 30 months. Abiraterone acetate (Zytiga $1 \mathrm{~g}$ per day) was used in seven patients $(2.5 \%)$, taxane based chemotherapy (docetaxel $75 \mathrm{mg} / \mathrm{m}^{2}$ ) was initiated in 43 patients (15.6\%) and distilbene ( $1 \mathrm{mg}$ per day) was administered in 38 patients (13.7\%). The remaining patients did not receive second-line treatment due to the co-morbidities associated with cardiovascular or thromboembolic events, and/or because the cost of secondline treatment was too high. Overall patient survival was $19.8 \pm 1.2$ months with a median of 13 months.

\section{Discussion}

The average age of our patients was 71.4 years. This is consistent with the fact that prostate cancer is more common in men over 70 years of age [5]. In many western series, prostate cancer is generally uncommon before the age of 45 and rare before the age of 50 (less than 1\% of cases in France) [9]. We noted the presence of metastatic prostate cancer in seven of our patients $(2.7 \%)$ who were aged 55 or younger. This higher incidence of prostate cancer in this age group in our series could be explained by the ethnic origin of our study population. Indeed, melanoderma patients have a higher risk of prostate cancer and of developing metastatic localisations earlier, and a twofold higher mortality rate compared to Caucasian patients [10, 11]. Oncogenetic consultation for gene mutations is strongly recommended in patients under 50 years of age with prostate cancer [12].

Furthermore, environmental exposure to chlordecone has been associated with a net increase in the incidence of prostate cancer in populations of African ethnic origin in the French West Indies [11, 13]. Patients in our series were not exposed to chlordecone and those under the age of 55 years did not have an oncogenetic consultation, as the latter is not yet performed in our country.

At the time of their cancer diagnosis, most of our patients already had symptomatic metastases. As a result, the circumstances of discovery were dominated by pain in the lumbar spine and altered general condition with a very high average total PSA $(1967.1 \mathrm{ng} / \mathrm{ml})$. A probable explanation for this finding would be the fact that health care remains inaccessible for a large part of the population of our country for three main reasons: the exorbitant cost of health care, the lack of generalised medical coverage and the non-reimbursement of health expenses. As a result, many patients most often come to consult late. Bone metastases $(82.6 \%)$ were the most frequent in our series. Bone is the preferred site for prostate cancer metastasis, as a result, bone metastases can be identified in more than $70 \%$ of patients with metastatic prostate cancer with a particular tropism for the lumbar vertebrae and pelvic bones [14]. However, we have noted two unusual sites of distant localisation of prostate cancer in our patients: ocular metastasis and testicular metastasis. These patients were initially operated on by colleagues for ocular and testicular tumours, and were referred to us following the identification of prostatic neoplastic cells during pathological examination of the surgical specimens.

The ocular localisation of prostate cancer is most often related to bone damage to the orbital floor, and less frequently to damage to the musculature or eyeball [15]. In regard to testicular localisation, the route of dissemination is not controlled and the lymphatics of the vas deferens may be the responsible drainage route [16].

Androgenic suppression was instituted in all patients in our series and consisted in the majority of cases of pulpectomy. The choice of surgical castration as the main method of androgenic suppression was mainly due to 
its low cost, half the cost of a single monthly injection of triptorelin for example [1]. In addition, pulpectomy provides androgen suppression from the twelfth hour onwards [17]. This rapidity of action is particularly useful in highly symptomatic patients (signs of slow spinal cord compression, bone pain, severe alteration of general condition) with a clear improvement in their quality of life.

Furthermore, although androgen suppression was considered the reference treatment for hormone-sensitive metastatic prostate cancer, it is now being replaced by combination therapies with new generation hormone therapies or Taxane-based chemotherapy. These combination therapies will depend on the tumour volume. For this purpose, in case of high tumour volume, androgen suppression can be combined with either Docetaxel or new generation hormone therapies regardless of tumour volume [4].

Tumor cytoreduction was associated with androgenic suppression in 89 patients with lower urinary obstructive tract disorders in our series. It appears to be of influence in metastatic prostate cancer. Indeed, studies have reported lower PSA nadir and better overall survival in patients with combined androgen suppression and tumor cytoreduction, compared to those with androgen suppression alone $[18,19]$.

Resistance to castration was observed in our patients between 6 and 30 months. The time of onset of this resistance is highly variable and during this period, tumor proliferation is dependent either on overexpression of the androgen receptor or on overexpression of the enzymes involved in androgen synthesis [8]. Second-line hormone therapies such as abiasterone acetate or enzalutamide and taxane-based chemotherapy are the best treatments for castration-resistant metastatic prostate cancer $[12,20]$. Few patients were able to access secondline treatment, and docetaxel-based chemotherapy was the most widely used in our series. This is explained by the decrease in the cost of a chemotherapy treatment, which has fallen since 2016 from 460,000 XOF (€701.3) to 85,000 XOF $(€ 129.6)$ in our hospital. Despite this significant drop in their price, second-line treatments are still not very accessible to patients in our country, where the minimum inter-professional growth wage (SMIC) is $52500 \mathrm{XOF}(80 €)$ per month. As a result, the overall survival of metastatic prostate cancer in our series was lower than that reported by other authors $[11,21]$.

\section{Conclusion}

Metastatic prostate cancer is diagnosed late in our developing country context. The majority of patients have metastases that are already symptomatic at the time of diagnosis of their cancer. Surgical castration is the most widely used androgenic suppression method because of its low cost. Taxane-based chemotherapy is the most commonly used second-line treatment for castration resistance, however, many patients cannot receive it because of financial limitations. These various limitations make it impossible to apply the international recommendations. Due to these factors, the overall survival rate for metastatic prostate cancer is poor in our hospital.

\section{Abbreviation \\ PSA: Prostate Specific Antigen}

\section{Acknowledgements}

None.

\section{Authors' contributions}

All authors have made a signifcant contribution to the fndings and methods in the paper. PAF worked on the idea and design. CZO, AS, AT shared in the editing. OS, NSN helped in data collection and analysis. AN shared in the editing. BS, BD, AKN contributed to revision. All authors read and approved the fnal manuscript. All authors read and approved the fnal manuscript.

Funding

No funding was obtained for this study.

\section{Availability of data and material}

The datasets used and/or analysed during the current study are available from the corresponding author on reasonable request.

\section{Declarations}

Ethics approval and consent to participate

The study protocol was approved by the ethics committee of the urology department of the CHU Aristide Le Dantec in Dakar. This committee is composed of senior professors. The approval number is not available. Verbal consent was obtained from all subjects. And this consent was approved by the ethics committee.

Consent for publication

Not applicable.

Competing interests

No competing interest is declared by any of the authors.

\section{Author details}

${ }^{1}$ Urology Department, University Hospital Center Aristide Le Dantec, Dakar, Senegal. ${ }^{2}$ Urology Department, Military Hospital of Ouakam, Dakar, Senegal. ${ }^{3}$ Urology Department, Dalal Diam, Dakar, Senegal.

Received: 30 December 2020 Accepted: 9 August 2021

Published online: 19 August 2021

References

1. Fall B, Tengue K, Sow Y, Sarr A, Thiam A, Mohamed S et al (2012) Place de la pulpectomie bilatérale dans la suppression androgénique pour cancer de la prostate. Prog Urol 22:344-349

2. Diallo AB, Bah I, Barry AM, Dombeu NY, Barry M, Diallo MB (2008) Caractéristiques épidémiologiques du cancer de la prostate en Guinée. Afr J Urol 14(3):161-167

3. Khalaf DJ, Annala M, Taavitsainen S, Finch DL, Oja C, Vergidis J et al (2019) Optimal sequencing of enzalutamide and abiraterone acetate plus prednisone in metastatic castration-resistant prostate cancer: a multicentre, randomised, open-label, phase 2, crossover trial. Lancet Oncol 20(12):1730-1739 
4. Rozet F, Mongiat-Artus $P$, Hennequin C, Beauval JB, Beuzeboc P, Cormier L et al (2020) French cCAFU guidelines-update 2020-2022: prostate cancer. Prog Urol 30:S136-\$251

5. Laramas M, Costan C, Tessier A, Farneti D (2011) Cancer de prostate métastatique résistant à la castration: le point de vue de l'oncologue médical. Med Nucl 35(6):378-383

6. Cancel-Tassin G, Cussenot O (2005) Genetic susceptibility to prostate cancer. BJU Int 96:1380-1385

7. Epstein J, Zelefsky MJ, Sjoberg DD, Nelson JB, Egevad L, Magi-Galluzzi C et al (2016) A contemporary prostate cancer grading system: a validated alternative to the Gleason score. Eur Urol 69(3):428-435

8. Beuzeboc P, Massard C (2015) Prise en charge du cancer de prostate résistant à la castration métastatique. Bull Cancer 102(6):509-515

9. Valeri A, Malavaud B, Desrichard O, Cornu JN, Blanchet P, Dervaux B et al (2010) Stratégies de diagnostic précoce et de prévention du cancer de la prostate. Bull Cancer 97(12):1499-1515

10. Jemal A, Siegel R, Xu J, Ward E (2010) Cancer statistics, 2010. CA A Cancer J Clin 60(5):277-300

11. Casenave J, Sénéchal C, Nevoux P, Gourtaud G, Tressières B, Blanchet $P$ (2014) Cancer de prostate non localisé au diagnostic en Guadeloupe. Prog Urol 24(3):167-172

12. Rozet $F$, Hennequin $C$, Beauval JB, Beuzeboc $P$, Cormier L, Fromont-Hankard G et al (2018) Recommandations françaises du Comité de Cancérologie de l'AFU - Actualisation 2018-2020: cancer de la prostate. Prog Urol 28(12):s79-s130

13. Multigner L, Ndong JR, Giusti A, Romana M, Delacroix-Maillard H, Cordier S et al (2010) Chlordecone exposure and risk of prostate cancer. J Clin Oncol 28(21):3457-3462
14. Coleman RE (1997) Skeletal complications of malignancy. Cancer 80(8):1588-1594

15. Bold HC, Nerard JA (1988) Orbital metastasis from prostate carcinoma. Arch Ophtalmol 106:1403-1408

16. Kirkali Z, Reid R, Deane RF, Kyle KF (1990) Silent testicular metastasis from carcinoma of the prostate. Br J Urol 66:205-207

17. Salomon L, Azria D, Bastide C, Beuzeboc P, Cormier L, Cornud F et al (2010) Recommandations en onco-urologie 2010. Prog Urol 20:217-252

18. Qin XJ, Ma CG, Ye DW, Yao XD, Zhang SL, Dai B et al (2012) Tumor cytoreduction results in better response to androgen ablation - a preliminary report of palliative transurethral resection of the prostate in metastatic hormone sensitive prostate cancer. Urol Oncol 30(2):145-149

19. Wang $Y$, Qin Z, Wang Y, Chen C, Wang Y, Meng X et al (2018) The role of radical prostatectomy for the treatment of metastatic prostate cancer: a systematic review and meta-analysis. Biosci Rep 38(1):BSR20171379

20. Ryan CJ, Smith MR, Fizazi K, Saad F, Mulders PFA, Sternberg CN et al (2015) Abiraterone acetate plus prednisone versus placebo plus prednisone in chemotherapy-naive men with metastatic castration-resistant prostate cancer (COU-AA-302): final overall survival analysis of a randomised, double-blind, placebo-controlled phase 3 study. Lancet Oncol 16(2):152-160

21. Hsiao W, Moses KA, Goodman M, Jani AB, Rossi PJ, Master VA (2010) Stage IV prostate cancer: survival differences in clinical T4, nodal and metastatic disease. J Urol 184(2):512-518

\section{Publisher's Note}

Springer Nature remains neutral with regard to jurisdictional claims in published maps and institutional affiliations.

\section{Submit your manuscript to a SpringerOpen ${ }^{\circ}$ journal and benefit from:}

- Convenient online submission

- Rigorous peer review

- Open access: articles freely available online

- High visibility within the field

- Retaining the copyright to your article

Submit your next manuscript at $\boldsymbol{\nabla}$ springeropen.com 